\title{
The avifauna and conservation status of the Río Nangaritza valley, southern Ecuador
}

\author{
C. S. BALCHIN and E. P. TOYNE
}

\section{Summary}

An ornithological survey was conducted in December 1994 at the lower Río Nangaritza valley in southern Ecuador, during which 181 species were recorded. These data combined with published records reveal the number of species known for this area to be 290. Of these, nine species are classified as globally vulnerable: Solitary Eagle Harpyhaliaetus solitarius, White-breasted Parakeet Pyrrhura albipectus, Spot-winged Parrotlet Touit stictoptera, Napo Sabrewing Campylopterus villaviscensio, Ecuadorean Piedtail Phlogophilus hemileucurus, Lanceolated Monklet Micromonacha lanceolata, Coppery-chested Jacamar Galbula pastazae, Fiery-throated Fruiteater Pipreola chlorolepidota and Orange-throated Tanager Wetmorethraupis sterrhopteron. Of the 290 species listed 115 are currently unrecorded in the adjacent Podocarpus National Park and therefore inhabit no protected area in southern Ecuador. Wildlife of the Nangaritza valley is threatened by gold mining, encroachment and hunting. Given the high avian diversity and the known botanical importance of the area plans to conserve the undisturbed forests of this region as part of a buffer zone for the adjacent Podocarpus National Park are recommended.

\section{Introduction}

Until the late 1980 os the avifauna of Zamora-Chinchipe Province in southern Ecuador remained little studied. Most of our knowledge was based on specimens collected around Zamora between 1857 and 1920 (Chapman 1926), with some more recent records from Ridgely (1980). More recently portions of the tropical and montane forested zones of the Cordillera del Cóndor, including the upper Río Nangaritza valley, have been explored (Marín et al. 1992, Krabbe and Sornoza 1994, Schulenberg and Awbrey 1997). In addition there is a checklist for the birds of Podocarpus National Park, less than $15 \mathrm{~km}$ west of Río Nangaritza (Rasmussen et al. 1994). The checklist is the result of much work in the area since the mid 1980s (Rahbek et al. 1995, Rasmussen et al. 1996). Within the ZamoraChinchipe portion of the Park, $80 \%$ of which is in this province, the avifauna in the Bombuscara and Romerillos areas are best known (Rahbek et al. 1995, Rahbek and Toyne 1996a,b, Figure 1). However, much of the south-east section of the Park remains unexplored, due to access problems caused by the Park's rugged topography. The valleys in this area are at a comparable elevation to the Nangaritza valley, so bird communities in the two areas may well be similar and surveys in the Nangaritza may provide clues as to what birds may be found in this part of the Park. 


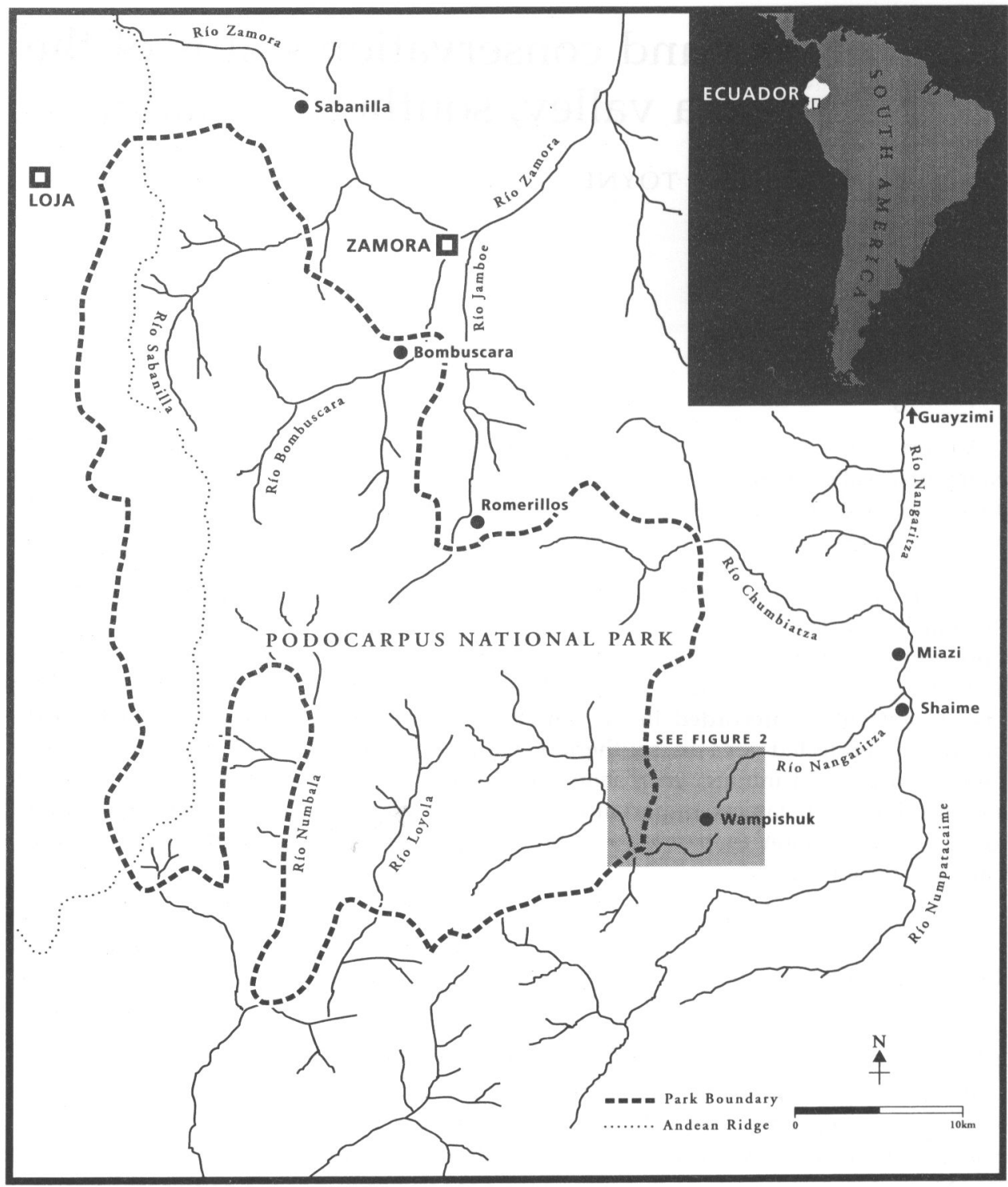

Figure 1. Location of the study area in relation to Podocarpus National Park.

Ornithological surveys of the Río Nangaritza have been confined to the northern end of the valley, with nothing recorded south of Shaime Military Post (Marín et al. 1992, Schulenberg and Awbrey 1997, Figure 1). Shaime area was classified as a key area for threatened birds principally because it was the only Ecuadorian locality for the endangered Orange-throated Tanager Wetmorethraupis sterrhopteron (Marín et al. 1992, Wege and Long 1995). Much of Podocarpus National Park and adjacent areas in both the Cordillera del Cóndor and the Río Nangaritza are threatened by goldmining (Toyne et al. 1992, Jiggins et al. unpubl. report, 1996, Schulenberg and Awbrey 1997). With this in mind, and the lack of 
records for the south-east corner of the Park, the aims of this study were to catalogue the avifauna and assess threats to the southern (lower) end of the Río Nangaritza valley.

In this paper we include observations made by the late Ted Parker III at Miazi, on the west slope of the Río Nangaritza valley (Figure 1). Parker's records are published in Conservation International's Rapid Assessment Program report on the Cordillera del Cóndor (Schulenberg and Awbrey 1997). We felt this work complemented our study and should be included as part of the general overview of the avifauna of the area.

\section{Background, study areas and methods}

The study area was situated at the southern end of the Cordillera del Cóndor in Zamora-Chinchipe Province, southern Ecuador, a low front-range of the eastern slope of the Andes (900-1300 m Toyne and Balchin 1996). Vegetational surveys around the Río Nangaritza from Paquisha south to Shaime have suggested this habitat is unique to this area of Ecuador (Palacios 1997). The area is home to the indigenous Shuar Indians who have traditionally lived in this part of southern Ecuador (Anon. 1978). The area south of Shaime is a Shuar Indian reserve, home to nine Shuar communities. However the area is rich in gold and the habitat and livelihood of the Shuars has been threatened by the influx of miners during the late 1980 s and 1990s. These miners are looking to establish another goldtown similar to nearby Nambija (Doltz 1989, Vallée 1992). Throughout the Province, including the Nangaritza valley, miners are polluting the environment with mercury which is used in the amalgamation process (Vallée 1992, F.Jiggins et al. unpubl. report 1996). Other settlers include members of the military and colonists who farm livestock and grow crops. They were encouraged to the area with the offer of free land rights by the government which was worried about losing territory to nearby Peru. Due to the problems associated with mining and colonization, such as deforestation and pollution, Palacios (1997) considered it urgent that the zone be declared a protected area by law.

Global positioning systems (Mag Pro 5000) were used to map coordinates and elevations of study sites. Fieldwork was conducted in December 1994 when the following areas of upper-tropical humid forest were investigated:

Shaime Military Post $\left({ }^{\circ} 4^{\circ} 20^{\prime} \mathrm{S}, 78^{\circ} 4 \mathrm{o}^{\prime} \mathrm{W}\right.$; $1000 \mathrm{~m}$ Figure 1 ): the disturbed mature forest at this settlement was briefly surveyed on 16 22-24 December.

The habitat surrounding the Mariposa Community, also referred to as Wampishuk $\left(04^{\circ} 22^{\prime} \mathrm{S}, 7^{\circ} 44^{\prime} \mathrm{W}\right.$ at $940 \mathrm{~m}$ Figures 1 and 2$)$, was surveyed during dry weather on the 17-18 and 21 December. This included the west bank of the Río Nangaritza and cultivated areas surrounded by semi-disturbed mature forest. The Mariposa Community was established by the Shuars in 1983 and now consists of 18 farms situated along the west bank of the Río Nangaritza and the Río Mariposa tributary.

The Rio Mariposa Camp ( $04^{\circ} 22^{\prime} \mathrm{S}, 78^{\circ} 45^{\prime} \mathrm{W}$ at $1000 \mathrm{~m}$ Figure 2) was made after a four-hour walk, north-west, from the Mariposa Community. The area surrounding the camp (1000-1200 $\mathrm{m}$ ) was surveyed between 17 and 21 December during overcast, rainy conditions, apart from the 21 December 


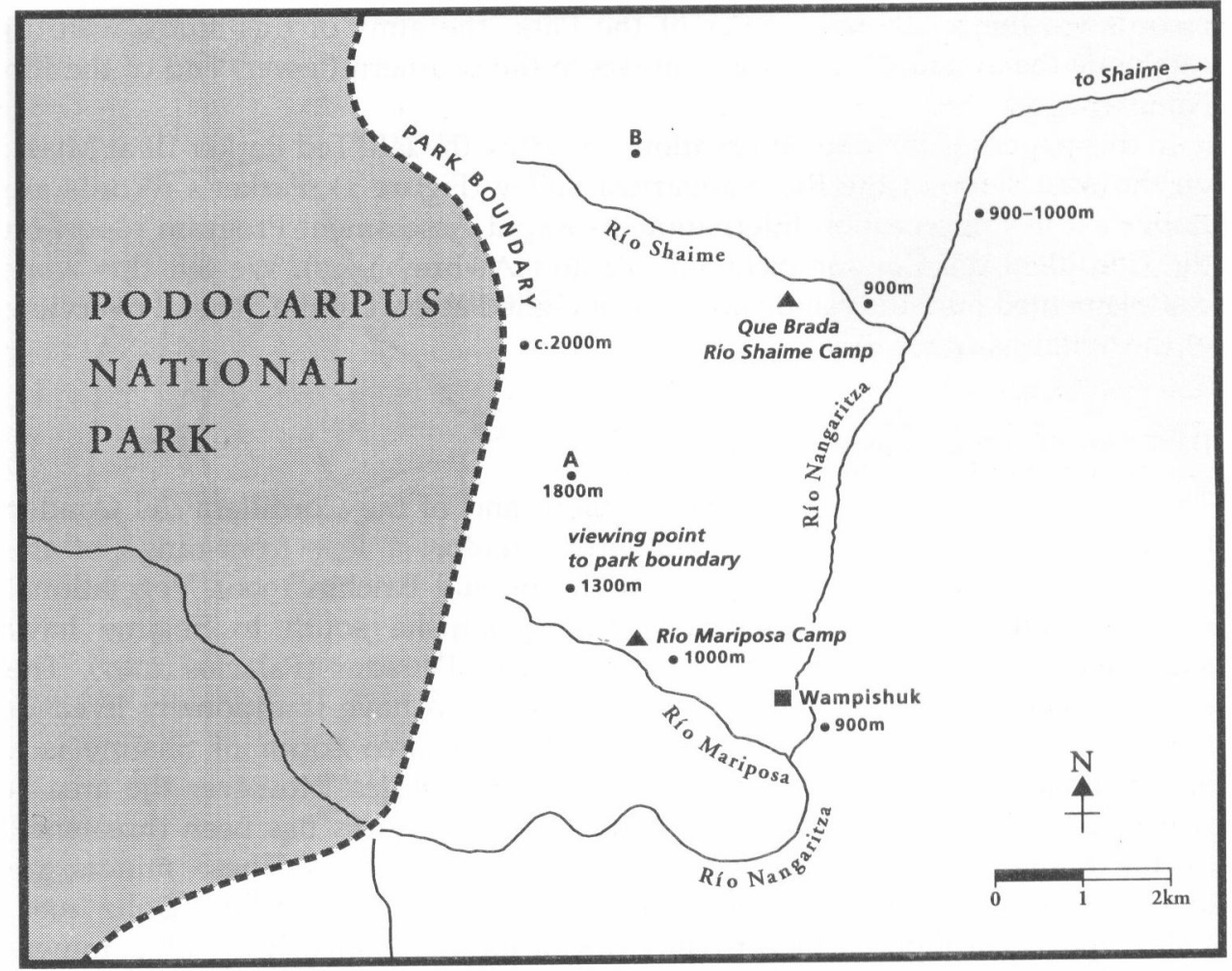

Figure 2. Location of the two camp sites in relation to Podocarpus National Park and the Río Nangaritza valley.

which was sunny with showers. The vegetation at this site was relatively undisturbed although there were some trails (less than I $\mathrm{m}$ wide) which Shuars used whilst hunting. The tropical humid forest consisted of tall $(40+\mathrm{m})$ emergent trees and a closed canopy at around $30 \mathrm{~m}$. There was some shrub vegetation and tree ferns (Cyatheaceae) were common. Denser vegetation was found along the river edge. Observations were made from walking Shuar trails and from vantage points along the Río Mariposa, which was shallow and $4 \mathrm{~m}$ wide. Whilst at this camp a trail ( $1 \frac{1}{2}$ hours walk) was made up to a ridge at $1300 \mathrm{~m}$. A further trail was cut to Position $\mathrm{A}$ at an elevation of $1800 \mathrm{~m} 3$ hours walk from the camp (Figure 2). From this point approximately $8 \mathrm{~km}$ of the boundary of the Podocarpus National Park could be seen (Instituto Ecuatoriano Forestal y Areas Naturales (INEFAN) Park boundary points 440455) and the status of the boundary was assessed for likely threats such as encroachment. The habitat encountered was pristine subtropical forest with shorter trees, dense bamboo understorey, and more shrub and ground vegetation than at the lower elevations.

The area surrounding a second camp, Quebrada Río Shaime $\left(04^{\circ} 22^{\prime} \mathrm{S}, 7^{\circ} 44^{\prime} \mathrm{W}\right.$ at $890 \mathrm{~m}$. Figure 2) was surveyed between 24 and 28 December during dry, mainly sunny (three out of four) days. Here habitat comprised of mature 
humid upper-tropical forest. The forest canopy was more open than the forest at the Río Mariposa Camp due to selective logging and trail cutting by Shuars. Observations were made from Shuar hunting trails on a northern ridge above the camp $(1000 \mathrm{~m})$, from a southern trail leading to the Río Nangaritza $(1000 \mathrm{~m})$ and from cultivated areas around the camp $(900-950 \mathrm{~m})$. On the 27 December the boundary of the Park was assessed at Position B (Figure 2: $04^{\circ} 21^{\prime} \mathrm{S}, 7^{\circ} 45^{\prime} \mathrm{W}$ at $900 \mathrm{~m}$; INEFAN Park boundary points $428-440$ ).

Observations were also made during the following journeys by boat along the Río Nangaritza: Guayzimi to Shaime Military Post, 6 and 16 December; Shaime Military Post to Mariposa, 7 December; Shaime Military Post to Guayzimi, 7 December, Shaime Military Post to Mariposa, 16 December, Mariposa to Shaime Military Post, 22 December; Shaime Military Post to Quebrada Río Shaime, 24 December; and Quebrada Rio Shaime to Shaime Military Post, 28 December.

Fieldwork between 6 and 22 December 1994 involved Pablo Andrade, C.S.B., Jeremy Flanagan, Orfa Rodriguez and E.P.T. Observations during 23-28 December were made by C.S.B. and E.P.T. For both periods additional records were supplied by Tracey-Ann Hooley and Jenny Rudston. The work included tape-recordings of vocalizations, mist-netting at Río Mariposa and Quebrada Río Shaime camps, and sight observations of birds. Sound recordings are deposited at the Wildlife Section of the National Sound Archives in London.

\section{Results}

A total of 181 bird species was recorded during the December 1994 survey (Appendix). Altogether 290 species have now been recorded for the southern end of the Nangaritza valley. These species are listed in the Appendix. Nine species, judged to be vulnerable (Collar et al. 1994), were recorded, although Lanceolated Monkbird Micromonacha lancelota is no longer regarded as threatened (Ridgely in litt. 1997). The eight threatened species are listed below.

Solitary Eagle Harpyhaliaetus solitarius: individual eagles were seen twice, at $1300 \mathrm{~m}$ above the Río Mariposa camp 21 December and soaring above the Rio Nangaritza between Mariposa and Shaime Military Post on 22 December.

White-breasted Parakeet Pyrrhura albipectus: the lower forested slopes of the Río Nangaritza valley were suspected to be ideal habitat for this parakeet (Toyne et al. 1992) but it was surprisingly not recorded. Instead, it was encountered only between 1300 and $1800 \mathrm{~m}$ above the Río Mariposa camp. In September 1997 a flock of about 20 were observed from Shaime village which is about $1 \mathrm{~km}$ downstream of Shaime Military Post (J. Flanagan in litt). The status within Podocarpus National Park (Toyne et al. 1992, Toyne 1996) and further north in the Cordilleras de Cutucú and del Cóndor (Robbins et al. 1987, Krabbe and Sornoza 1994, Schulenberg and Awbrey 1997) suggest the species is not as severely threatened as first feared.

Spot-winged Parrotlet Touit stictoptera: was recorded at Miazi and elsewhere in the Cordillera del Cóndor (Schulenberg and Awbrey 1997). This parrotlet is regarded as vulnerable (Collar et al. 1994). Within southern Ecuador it has been recorded further north in the Cordillera de Cutucú, Morona-Santiago Province and further south at Zumba in Zamora-Chinchipe (Collar et al. 1992). The 
Nangaritza valley should provide suitable habitat within the species's elevational range, which is between 1000 and $1700 \mathrm{~m}$ (Collar et al. 1992)

Napo Sabrewing Campylopterus villaviscensio: three individuals were seen around the Quebrada Río Shaime camp clearing on 27 and 28 December. They were more often heard than they were seen. Their call was similar to the "chink" call of Sparkling Violetear Colibri coruscans. Adult Napo Sabrewing plumage recalls that of Fork-tailed Woodnymph Thalurania furcata with the underpart colours reversed, so it is possible on brief views that they will be overlooked. One individual was mist-netted. It had buffy malar stripes and dusky greyish underparts with reduced purple throat patches. These latter markings were not noticeable on adult skins examined in collections at the British Museum (Natural History) and Museo de Ciencias Naturales (Quito), so it is possible that the individual was a juvenile, but little is known about plumage variation within this species.

Ecuadorian Piedtail Phlogophilus hemileucurus: surprisingly not seen or heard at the Quebrada Río Shaime camp. They were regularly heard, a single hermitlike note given from the undergrowth, at Mariposa Camp, although only two were observed.

Coppery-chested Jàcamar Galbula pastazae: observations of a pair at $1300 \mathrm{~m}$ above the Río Mariposa camp were not surprising as it is now known from the Zumba region further south (R. S. Ridgely and P. J. Greenfield unpubl. data, Paul Coopmans pers. comm. 1997), throughout Ecuador to southern Colombia on the lower slopes of the eastern Andes (Poulsen and Wege 1994). Its current status is probably no longer threatened.

Fiery-throated Fruiteater Pipreola chlorolepidota: one male was seen in the forest behind the Shaime Military Post on 23 December and another individual (sex not determined) was seen on the northern ridge above the Quebrada Río Shaime camp on 27 December.

Orange-throated Tanager Wetmorethraupis sterrhopteron: this unmistakable tanager was only recorded at Miazi (Schulenberg and Awbrey 1997). It was absent further south during this survey. This result was disappointing as the tanager had previously been recorded in July 1990 in the same forest as we had searched at Shaime Military Post (Marín et al. 1992, J. M. Carrion pers. comm. 1995) and they are known to occur in both disturbed and undisturbed mature forest in north-eastern Peru (Ridgely and Tudor 1989, Marín et al. 1992, Schulenberg and Awbrey 1997).

During the December 1994 survey 26 species were recorded at the upper limit of their elevation range, four of which represent noticeable elevational records (Table 1). Also of interest were 26 species that were recorded along the Río Nangaritza valley which were previously only known from Chapman (1926), denoted as PC in the appendix. One hundred and fifteen species (39\%) of the 292 species known for the Nangaritza, including the former 26 species, have not been recorded for Podocarpus National Park.

The following observations also deserve attention.

Yellow-throated Bush-tanager Chlorospingus flavigularis: this species was the main constituent of all feeding flocks of tanagers observed at the Río Mariposa camp, however it was rarely encountered at the Quebrada Río Shaime camp. As both sites were at the same altitude we can only guess that their rare occurrence 
Table 1. Species recorded at the upper limit of their known elevation ranges in the Río Nangaritza valley during December 1994

\begin{tabular}{|c|c|c|}
\hline Species & Location and elevation & Known elevation range \\
\hline Aratinga weddellit ${ }^{a}$ & $\mathrm{RN} ; 900 \mathrm{~m}$ & to $500 \mathrm{~m}^{* * *}$ \\
\hline Forpus sclateri & $\mathrm{RN} ; 900 \mathrm{~m}$ & to $900 \mathrm{~m}$ (RSR) \\
\hline Brotogeris cyanoptera ${ }^{a}$ & $\mathrm{RN}, \mathrm{QRS} ; 900-1000 \mathrm{~m}$ & to $800 \mathrm{~m}(\mathrm{NK})$ \\
\hline Campylopterus largipennis ${ }^{n}$ & $\mathrm{MC}, \mathrm{RMC} ; 950-1200 \mathrm{~m}$ & to $750 \mathrm{~m}$ (RSR) \\
\hline Pteroglossus azara & QRS; $1000 \mathrm{~m}$ & to $1000 \mathrm{~m}$ (RSR) \\
\hline Selenidera reinwardtii & $\mathrm{M} ; 1000 \mathrm{~m}$ & to $1200 \mathrm{~m}(\mathrm{NK})$ \\
\hline Metopothrix aurantiacus & $\mathrm{MC} ; 950 \mathrm{~m}$ & $\begin{array}{l}\text { to } 900 \mathrm{~m}(\mathrm{PC}), \text { but to } 1000 \mathrm{~m} \text { in } \mathrm{S} \\
\text { Peru }^{* *}\end{array}$ \\
\hline Myrmotherula axillaris & QRS; RMC; 900-1200 m & to $900 \mathrm{~m}^{* *}$ \\
\hline Cercomacra cinerascens & QRS; $950 \mathrm{~m}$ & $\begin{array}{l}\text { to } 900 \mathrm{~m}(\mathrm{NK}) \text {, but to } 1150 \mathrm{~m} \text { in } \mathrm{S} \\
\text { Peru** }\end{array}$ \\
\hline Myrmoborus myotherinus & QRS; $1000 \mathrm{~m}$ & to $1300 \mathrm{~m}$ (RSR) \\
\hline Hylophylax naevia & QRS; $1000 \mathrm{~m}$ & $\begin{array}{l}\text { to } 1000 \mathrm{~m} \text { but to } 1360 \mathrm{~m} \text { in Ven- } \\
\text { zuela** }\end{array}$ \\
\hline Pithys albifrons & $\mathrm{MC}, \mathrm{RMC} ; 94^{\circ-1200 \mathrm{~m}}$ & mostly below $1000 \mathrm{~m}^{* *}$ \\
\hline Formicarius analis & QRS; $1000 \mathrm{~m}$ & to $1100 \mathrm{~m}^{* *}$ \\
\hline Corythopis torquata & QRS; $1000 \mathrm{~m}$ & $\begin{array}{l}\text { mostly below } 1000 \mathrm{~m} \text { less often } \\
\text { up to } 1500 \mathrm{~m}^{* *}\end{array}$ \\
\hline Rhynchocyclus olizaceus & QRS: $1000 \mathrm{~m}$ & to $1000 \mathrm{~m}(\mathrm{NK})$ \\
\hline Platyrinchus coronatus ${ }^{a}$ & $\mathrm{MC} ; 940 \mathrm{~m}$ & $\begin{array}{l}\text { mainly below } 1000 \mathrm{~m} \text { but to } 1300 \\
\text { in SW Ecuador }\end{array}$ \\
\hline Pipra erythrocephala & QRS; $1000 \mathrm{~m}$ & to $1100 \mathrm{~m}^{* *}$ \\
\hline Manacus manacus & $\mathrm{RMC} ; 1000-1200 \mathrm{~m}$ & $\begin{array}{l}\text { mainly below } 500 \mathrm{~m} \text { recorded to } \\
1300 \mathrm{~m} \text { in Venezuela }\end{array}$ \\
\hline Tyranneutes stolzmanni. & QRS; $950 \mathrm{~m}$ & to $1000 \mathrm{~m}^{* *}$ \\
\hline Piprites chloris & QRS; $1100 \mathrm{~m}$ & to $500 \mathrm{~m}$ occasionally to $1300 \mathrm{~m}^{* *}$ \\
\hline Cyanocorax violaceus & $\mathrm{RN} ; 900-950 \mathrm{~m}$ & to $1000 \mathrm{~m}^{*}$ \\
\hline Thryothorus coraya & $\mathrm{S} ; 1000 \mathrm{~m}$ & to $1000 \mathrm{~m}^{*}$ \\
\hline Microcerculus marginatus & QRS, MC; 950-1200 m & $\begin{array}{l}\text { to } 1000 \mathrm{~m} \text { to } 1800 \mathrm{~m} \text { in Vene- } \\
\text { zuela* }\end{array}$ \\
\hline Hemithraupis flavicollis & QRS; $950 \mathrm{~m}$ & to $800 \mathrm{~m}^{* *}$ \\
\hline Dacnis flaviventer & $\mathrm{S}, \mathrm{QRS} ; 950-1000 \mathrm{~m}$ & $\begin{array}{l}\text { to } 500 \mathrm{~m} \text { occasionally to } 1400 \mathrm{~m} \text { in } \\
\text { Bolivia * }\end{array}$ \\
\hline Cacicus cela & $\mathrm{RN} ; 900-950 \mathrm{~m}$ & to $900 \mathrm{~m}^{*}$ \\
\hline
\end{tabular}

See Appendix for key to location names. "Species recorded at a noticeable increase in elevation $(+200 \mathrm{~m})$. Upper limits to elevation ranges are taken from Ridgely and Tudor $1989^{*}, 1994^{* *}$ and Hilty and Brown $1986^{* * *}$ and from unpublished records of the following: RSR, Robert Ridgely; NK, Niels Krabbe; PC, Paul Coopmans; ${ }^{b}$. stolzmanni was listed for Zamora (950-1000 $\mathrm{m}$ ) by Chapman (1926) but most literature does not refer to this record.

at the latter area was related to vegetational difference between the two sites. In general they inhabit the humid foothills and lower subtropical forests between 700 and $1600 \mathrm{~m}$ (Ridgely and Tudor 1989).

Blue-gray Tanager Thraupis episcopus: an adult observed feeding a juvenile near the Río Mariposa camp showed characteristics of the nominate race, as it lacked whitish shoulders (Ridgely and Tudor 1989).

Slaty-capped Shrike-vireo Vireolanius leucotis: a single bird was seen along the trail near the river south of the Quebrada Río Shaime camp on 24 December. Its ear coverts were all yellow and it did not show a white cheek stripe typical of the race expected in this area (Ridgely and Tudor 1989). 


\section{Discussion}

The Shuars at Mariposa knew of the existence of Podocarpus National Park and the approximate location of the boundary. They also realized the importance of the Park, as it provided their main source of potable water, and they were worried about the possible pollution of the rivers by potential gold mining activities.

The main threat to the wildlife in the portion of Río Nangaritza valley we surveyed was from hunting. No primates were encountered and the local indians said that woolly monkey Lagothrix lagothrix and other monkeys used to be common. Overhunting by the Shuars and, to a lesser extent, habitat destruction has doubtless caused a decline in large mammal numbers. The Shuars still hunt but their quarry is now medium-sized birds such as parrots and toucans. Shuars rely upon domesticated animals such as chickens and pigs, and crops like banana and plantain for food, some of which are traded in Guayzimi for goods (J. Rivadeneira, unpubl. report, 1996).

The eastern Andean slopes from the boundary ridge of the Podocarpus National Park between Quebrada Río Shaime and the Río Mariposa consisted of pristine subtropical forest but most of this area is under mining concessions (Schulenberg and Awbrey 1997). The nearest settlement to the Park was a farm with one inhabitant. The Shuar's current rate of colonization is slow as it is only when a son leaves the family home (6-12 people) to start a family that forest is cleared for settlement and there was little immigration from other areas. This suggested that encroachment was not a threat to the Park's status in this area. However the status of the Park's north-eastern boundary should be investigated as the Shuar communities living along the Rio Nangaritza and the Río Chumbiatza, downstream from Shaime (Figure 1) are four times larger than the 100-120 people at Mariposa. The Río Chumbiatza communities are close to the north-east boundary of Podocarpus National Park and encroachment into the Park may occur here (Figure 1).

Considering the limited survey time the high number of species found, many of which occur at their upper elevational limit, suggested that this area contains a high degree of avian richness. The lower number of bird species recorded at the Río Mariposa Camp compared with those recorded at Quebrada Río Shaime can be attributed to poorer weather and background noise of the Rio Mariposa which made hearing difficult at the former site. This work was only a preliminary survey and further work in this area is encouraged.

Whether or not some birds found in the Nangaritza also occur in Podocarpus National Park remains unknown. It is reasonable to assume that 26 species have been sensitive to the deforestation that has taken place around Zamora after 1920, as they have not been recorded since 1920 (Appendix). Chapman (1926) described Zamora as a small frontier settlement of about 8-1o huts, which is comparable to the present day Mariposa Community. However, since the gold boom in the late 1970s and early 1980 the frontier has moved, Zamora has grown and other towns, such as Nambija and Guayzimi, have been established further east (Doltz 1989). As deforestation resulting from gold mining and colonists' activities continues these species and possibly others could become locally extinct. One solution to this potential problem could be the creation of a buffer zone that stretches east from Podocarpus National Park's eastern boundary to 
the Río Nangaritza. This would lead to a $16 \%$ increase (552 to 641 species) in birds known for the Park. There would need to be controls on the type and levels of hunting by Shuar Indians allowed within the zone. But if an agreement could be reached between the Shuar Indians and the Park authorities protected status could be given to the area and any form of mineral exploration outlawed. For this to happen the Ecuadorian laws would need to be changed and this could be a long and complicated process. However, the buffer zone would provide the Shuars with a reserve free from interference from gold mining. The nearest lowland Amazonian protected habitat in Ecuador is Yasuni National Park, some $300 \mathrm{~km}$ north-east of the Nangaritza area so a buffer zone would provide a habitat for many bird species whose habitat in southern Ecuador at present remains unprotected.

\section{Acknowledgments}

This paper results from Imperial College's Parrots in Peril Expedition 1994. We would like to dedicate the paper to the late Ted Parker whose data have contributed to our understanding of the Nangaritza's avifauna. We thank P. Andrade, J. Flanagan, T-A. Hooley, O. Rodriguez and J. Rudston who assisted with fieldwork. INEFAN and Museo Ecuatoriano de Ciencias Naturales, Quito issued the necessary permits. Personnel from INEFAN in Loja and Zamora, Fundación Ecologia Arcoiris and the Ministerio de Defensa in Zamora and at Shaime Military Post provided logistical help, especially Colonel Mancheno of the 52nd Jungle Battalion, as did the people of Guayzimi, particularly Hector. We also thank the people of Mariposa Community for permission to enter their land and to Ramón Tiwi and Enrique Nutip for expertly guiding us through the jungle. Ned Jolliffe at WWF drew the figures. The expedition was supported by a BP BirdLife International and Fauna and Flora International expedition award and grants from the British Ornithologists' Union, the Bird Exploration Fund, Imperial College Exploration Board, The Parrot Society of the U.K., The World Parrot Trust, Wildwings. Niels Krabbe kindly identified some birds from tape recordings and made his unpublished records available, as did Paul Coopmans, Paul Greenfield and Robert Ridgely. Paul Coopmans, Niels Krabbe, Robert Ridgely and Thomas Schulenberg kindly made useful comments on previous drafts of this paper.

\section{Appendix}

Taxonomy and nomenclature follow as closely as possible that given by Ridgely and Greenfield (in prep.) and used by Williams et al. (1996). Species that have not been recorded for Podocarpus National Park are denoted ${ }^{\mathrm{P}}$ or ${ }^{\mathrm{PC}}$ if they have only been recorded for Zamora by Chapman (1926). Due to the limited period spent at each location we feel that it might be misleading to give levels of abundance; instead presence $(X)$ is recorded. Observations made on the Río Nangaritza (RN) north of Shaime Military Post and including Guayzimi, are denoted ${ }^{\mathrm{N}}$, and observations made on the Río Nangaritza south of Shaime Military Post are denoted $^{S}$ and Shaime Military Post by S; QRS, Quebrada Río Shaime camp; MC, Mariposa community; RMC, Río Mariposa camp; M, Miazi (see Schulenberg and 
Awberry 1997). Species observed above RMC between 1300 and $1800 \mathrm{~m}$ are denoted by *. Pipreola chlorolepidota, Hyloctistes subulatus, Hylophylax naevia, Machaeropterus regulus are new records for Podocarpus National Park not given in Rasmussen et al. 1994 (P. Coopmans and P. Greenfield pers. comm. 1997). Species listed as " $\mathrm{sp}^{\prime}$ are only included in counts if no other member of that family was located, i.e. Xenops sp. is not included in the overall species count as two other Xenops were identified.

\begin{tabular}{|c|c|c|c|c|c|c|}
\hline Species & $\mathrm{RN}$ & $\mathrm{S}$ & QRS & $\mathrm{MC}$ & RMC & M \\
\hline Little Tinamou Crypturellus soui & & & & & & $x$ \\
\hline Brown Tinamou Crypturellus obsoletus & & & $x$ & & & \\
\hline Striated Heron Butorides striatus ${ }^{\mathrm{PC}}$ & $X^{s}$ & & & & & \\
\hline Cattle Egret Bubulcus ibis ${ }^{\mathrm{P}}$ & $X^{5}$ & & & & & \\
\hline Snowy Egret Egretta thula ${ }^{\mathrm{P}}$ & $X^{5}$ & & & & & \\
\hline King Vulture Sarcoramphus papa ${ }^{\mathrm{P}}$ & $X^{\mathrm{N}}$ & & & & & \\
\hline Turkey Vulture Carthartes aura & & & & & & $\mathrm{x}$ \\
\hline $\begin{array}{l}\text { Greater Yellow-headed Vulture Cathartes } \\
\text { melambrotus }\end{array}$ & $X^{5}$ & $x$ & $x$ & $x$ & & \\
\hline Swallow-tailed Kite Elanoides forficatus & $X^{5}$ & & $x$ & $x$ & $x$ & $x$ \\
\hline Plumbeous Kite Ictinia plumbea & & & & & $\mathrm{x}$ & \\
\hline Solitary Eagle Harpyhaliaetus solitarius & $X^{s}$ & & & & $x$ & \\
\hline Roadside Hawk Buteo magnirostris & $X^{5}$ & & & & & $x$ \\
\hline Short-tailed Hawk Buteo brachyurus & & & & & $x$ & $x$ \\
\hline Black Caracara Daptrius ater & $X^{s}$ & & & $\mathrm{x}$ & $x$ & $x$ \\
\hline Barred Forest-falcon Micrastur ruficollis & & & & & & $\mathrm{x}$ \\
\hline Laughing Falcon Herpetotheres cachinnans & & & & & $x$ & $x$ \\
\hline Bat Falcon Falco rufigularis & & & $\mathrm{x}$ & $\mathrm{x}$ & & \\
\hline Grey-breasted Crake Laterallus exilis ${ }^{\mathrm{P}}$ & & & & & & $\mathrm{x}$ \\
\hline $\begin{array}{l}\text { Chestnut-headed Crake Anurolimnas } \\
\text { castaneiceps }^{\mathrm{PC}}\end{array}$ & & & & $\mathrm{x}$ & & $x$ \\
\hline Blackish Rail Pardirallus nigricans & & & & & & $x$ \\
\hline Spotted Sandpiper Actitis macularia & $X^{\mathrm{NS}}$ & $x$ & & $x$ & & \\
\hline Scaled Pigeon Columba speciosa $a^{\mathrm{PC}}$ & & $x$ & & $x$ & & \\
\hline Pale-vented Pigeon Columba cayennensis ${ }^{\mathrm{P}}$ & $X^{5}$ & $x$ & & & & \\
\hline Ruddy Pigeon Columba subrinacea & & & & $\mathrm{x}$ & & \\
\hline Plumbeous Pigeon Columba plumbea & & & & $x$ & & $x$ \\
\hline Grey-fronted Dove Leptotila rufaxilla & & & & $x$ & & $x$ \\
\hline Sapphire Quail-dove Geotrygon saphirina & & & & & & $x$ \\
\hline Ruddy Quail-dove Geotrygon montana & & & & & $x$ & \\
\hline Chestnut-fronted Macaw Ara severa ${ }^{\mathrm{P}}$ & $X^{s}$ & $x$ & & & & \\
\hline White-eyed Parakeet Aratinga leucophthalmus & $X^{s}$ & $x$ & & $x$ & $x$ & \\
\hline Dusky-headed Parakeet Aratinga weddellii ${ }^{\mathrm{P}}$ & $X^{5}$ & & $x$ & & & \\
\hline White-necked Parakeet Pyrrhura albipectus & & & $X^{*}$ & & & \\
\hline Dusky-billed Parrotlet Forpus sclateri ${ }^{\mathrm{PC}}$ & $x^{s}$ & & & & & $x$ \\
\hline Cobalt-winged Parakeet Brotogeris cyanoptera ${ }^{\mathrm{P}}$ & $x^{5}$ & & $x$ & & & $x$ \\
\hline Spot-winged Parrotlet Touit stictoptera ${ }^{\mathrm{P}}$ & & & & & & $x$ \\
\hline Blue-headed Parrot Pionus menstruus & $X^{s}$ & & $x$ & $x$ & $x$ & $x$ \\
\hline Mealy Amazon Amazona farinosa ${ }^{\mathrm{P}}$ & & & $x$ & & & \\
\hline Squirrel Cuckoo Piaya cayana & & $x$ & & & & $x$ \\
\hline Little Cuckoo Piaya minuta $^{\mathrm{P}}$ & & & & & & $\mathrm{x}$ \\
\hline Band-bellied Owl Pulsatrix melanota & & & & & & $x$ \\
\hline Pauraque Nyctidromus albicollis & & & & & & $\mathrm{x}$ \\
\hline White-collared Swift Streptoprocne zonaris & & & $\mathrm{x}$ & & & \\
\hline Chestnut-collared Swift Streptoprocne rutilus & & & & & & $x$ \\
\hline Grey-rumped Swift Chaetura cinereiventris & & & & & & $x$ \\
\hline
\end{tabular}




\begin{tabular}{|c|c|c|c|c|c|c|}
\hline Species & $\mathrm{RN}$ & $S$ & QRS & $\mathrm{MC}$ & $\mathrm{RMC}$ & M \\
\hline White-tipped Swift Aeronautes montivagus ${ }^{P}$ & & & & & & $x$ \\
\hline Pale-tailed Barbthroat Threnetes leucurus & & & $x$ & & $x$ & $x$ \\
\hline Green Hermit Phaethornis guy & & & $x$ & & $x$ & $\mathrm{x}$ \\
\hline Long-tailed Hermit Phaethornis superciliosus & & & & & & $\mathrm{x}$ \\
\hline Grey-chinned Hermit Phaethornis griseogularis & & $\mathrm{x}$ & $\mathrm{x}$ & $x$ & $x$ & $x$ \\
\hline Little Hermit Phaethornis longuemareus ${ }^{\mathrm{P}}$ & & & & & & $x$ \\
\hline Sicklebill sp. Eutoxeres sp. & & $x$ & & $x$ & & \\
\hline $\begin{array}{l}\text { Grey-breasted Sabrewing Campylopterus } \\
\text { largipennis }\end{array}$ & & & & $\mathrm{x}$ & $x$ & $\mathrm{x}$ \\
\hline Napo Sabrewing Campylopterus villaviscensio & & & $x$ & & & \\
\hline Violet-headed Hummingbird Klais guimeti & & & & & & $x$ \\
\hline Hummingbird sp. Chlorestes $s p ?$ & & & $x$ & & & \\
\hline Fork-tailed Woodnymph Thalurania furcata & & & $x$ & & & $\mathrm{x}$ \\
\hline Speckled Hummingbird Adelomyia melanogenys & & & & & & $\mathrm{x}$ \\
\hline Ecuadorian Piedtail Phlogophilus hemileucurus & & & & & $x$ & \\
\hline Black-throated Brilliant Heliodoxa schreibersii & & & & & & $\mathrm{x}$ \\
\hline Black-eared Fairy Heliothryx aurita & & & & $x$ & $x$ & $x$ \\
\hline White-tailed Trogon Trogon viridis ${ }^{P}$ & & & & & & $\mathrm{x}$ \\
\hline Collared Trogon Trogon collaris ${ }^{\mathrm{PC}}$ & & & $\mathrm{x}$ & & $\mathrm{x}$ & $x$ \\
\hline Blue-crowned Trogon Trogon curucui ${ }^{\mathrm{P}}$ & & & & & & $\mathrm{X}$ \\
\hline Ringed Kingfisher Megaceryle torquata ${ }^{\mathrm{P}}$ & $X^{s}$ & $x$ & & & & $\mathrm{X}$ \\
\hline Amazon Kingfisher Chloroceryle amazona & $X^{N S}$ & & & $x$ & $\mathrm{x}$ & \\
\hline Green Kingfisher Chloroceryle americana & & & & & & $\mathrm{X}$ \\
\hline Highland Motmot Momotus aequatorialis & & & & & & $\mathrm{x}$ \\
\hline Coppery-chested Jacamar Galbula pastazae & & & & & $X^{*}$ & \\
\hline $\begin{array}{l}\text { Purplish Jacamar Galbula (leucogastra) } \\
\text { cahlocothrax }\end{array}$ & & & & & & $x$ \\
\hline Puffbird sp.Malacoptila sp. & & & & & & $x$ \\
\hline Lanceolated Monklet Micromonacha lanceolata & & & & & & $x$ \\
\hline
\end{tabular}

Black-spotted Barbet Capito niger'

Lemon-throated Barbet Eubucco richardsoni ${ }^{\text {p }}$

Red-headed Barbet Eubucco bourcierii

Chestnut-tipped Toucanet Aulacorhyncus derbianus

Many-banded Aracari Pteroglossus pluricinctus ${ }^{p}$

Ivory-billed Aracari Pteroglossus azara ${ }^{\mathrm{P}}$

Golden-collared Toucanet Selenidera reinwardtii ${ }^{P}$

Yellow-ridged Toucan Ramphastos culminatus ${ }^{\mathrm{PC}}$

$x$

$x$

$x$

Black-mandibled Toucan Ramphastos ambiguus

White-throated Toucan Ramphastos tucanus ${ }^{\mathrm{P}}$

Lafresnaye's Piculet Picumnus lafresnayi

Golden-olive Woodpecker Piculus rubiginosus

White-throated Woodpecker Piculus leucolaemus ${ }^{\mathrm{P}}$

$x$

$\mathrm{X}$

$\mathrm{X}$

$x$

$\mathrm{X}$

Yellow-tufted Woodpecker Melanerpes cruentatus

Smoky-brown Woodpecker Veniliornis fumigatus

Little Woodpecker Veniliornis passerinus

Red-stained Woodpecker Veniliornis affinis ${ }^{\mathrm{p}}$

Lineated Woodpecker Dryocopus lineatus

Crimson-crested Woodpecker Campephilus melanoleucus

Crimson-bellied Woodpecker Campephilus haematogaster

Dusky Spinetail Synallaxis moesta ${ }^{\mathrm{PC}}$

Dark-breasted Spinetail Synallaxis albigularis 


Species
Speckled Spinetail Cranioleuca gutturata
Orange-fronted Plushcrown Metopothrix

aurantiacus $^{\mathrm{P}}$

Spotted Barbtail Premnoplex brunnescens

Striped Woodhaunter Hyloctistes subulatus ${ }^{p}$

Lineated Foliage-gleaner Syndactyla subalaris

Montane Foliage-gleaner Anabacerthia striaticollis

Rufous-rumped Foliage-gleaner Philydor erythrocercus

Rufous-tailed Foliage-gleaner Philydor ruficaudatus

Dusky-cheeked Foliage-gleaner Automolus dorsalis $^{\mathrm{PC}}$

Buff-throated Foliage-gleaner Automolus ochrolaemus $^{\mathrm{P}}$

RN S QRS

QRS

$\mathrm{MC}$

RMC M

Ruddy Foliage-gleaner Automolus rubiginosus ${ }^{\mathrm{P}}$

Xenops sp. Xenops sp.

Streaked Xenops Xenops rutilans

Plain Xenops Xenops minutus ${ }^{P}$

Tawny-throated Leaftosser 'Sclerurus mexicanus ${ }^{\mathrm{PC}}$

Long-tailed Woodcreeper Deconychura longicauda $a^{\mathrm{PC}}$

Wedge-billed Woodcreeper Glyphorhynchus spirurus

Olivaceous Woodcreeper Sittasomus griseicapillus

Barred Woodcreeper Dendrocolaptes certhia ${ }^{\mathrm{P}}$

Ocellated Woodcreeper Xiphorhynchus ocellatus

Buff-throated Woodcreeper Xiphorhynchus guttatus $^{\mathrm{P}}$

Olive-backed Woodcreeper Xiphorhynchus triangularis

Lineated Woodcreeper Lepidocolaptes albolineatus $^{\mathrm{P}}$

Sicklebill sp. Campylorhampus sp. ${ }^{\mathrm{P}}$

Fasciated Antshrike Cymbilaimus lineatus ${ }^{p}$

Lined Antshrike Thamnophilus tenuepunctatus

White-shouldered Antshrike Thamnophilus aethiops ${ }^{p}$

Plain-winged Antshrike Thamnophilus schistaceus ${ }^{\mathrm{PC}}$

Russet Antshrike Thamnistes anabatinus

Plain Antvireo Dysithamnus mentalis

Dusky-throated Antshrike Thamnomanes ardesiacus $^{\mathrm{P}}$

Pygmy Antwren Myrmotherula brachyura ${ }^{P}$

Stripe-chested Antwren Myrmotherula longicauda

Foothill Antwren Myrmotherula spodionota

White-flanked Antwren Myrmotherula axillaris ${ }^{p}$

Slaty Antwren Myrmotherula schisticolor

$\chi^{s}$

$\mathrm{X}$

X

$x$

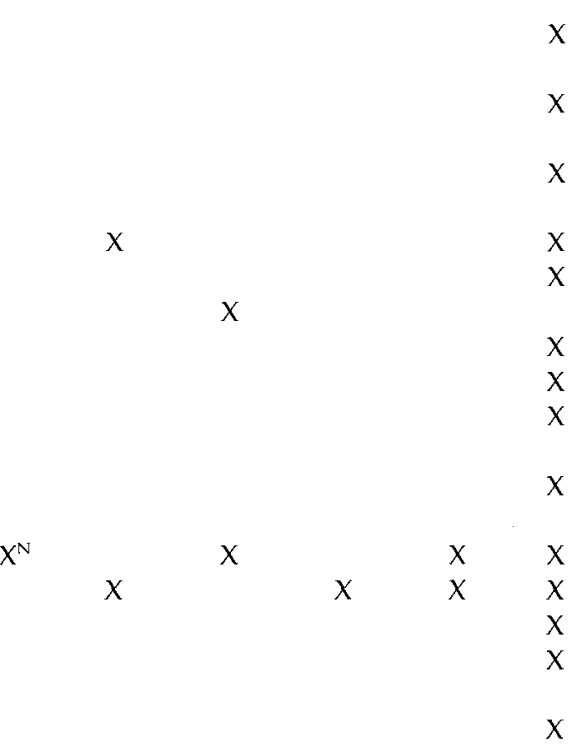

X

$\mathrm{X}$

$x$

$\mathrm{X}$

$x$

$x$

$x$

$x$

$x$

$\mathrm{X}$

$x$

$x$

$x$

$x \quad x \quad x$

Long-winged Antwren Myrmotherula longipennis $^{\mathrm{P}}$

Grey Antwren Myrmotherula menetriesii

Rufous-winged Antwren Herpsilochmus rufimarginatus

$x$

Antwren sp. Terenura sp. 


\begin{tabular}{|c|c|c|c|c|c|c|}
\hline Species & $\mathrm{RN}$ & $\mathrm{S}$ & QRS & MC & $\mathrm{RMC}$ & $\mathrm{M}$ \\
\hline Grey Antbird Cercomacra cinerascens ${ }^{\mathrm{P}}$ & & & $\mathrm{x}$ & & & $\mathrm{x}$ \\
\hline Black Antbird Cercomacra serva" & & & & & & $x$ \\
\hline White-browed Antbird Myrmoborus leucophrys & & & & $x$ & & $\mathrm{x}$ \\
\hline Black-faced Antbird Myrmoborus myotherinus ${ }^{\mathrm{P}}$ & & & $x$ & & & $x$ \\
\hline Warbling Antbird Hypocnemis cantator & & & $\mathrm{x}$ & & & $x$ \\
\hline Spot-backed Antbird Hylophylax naevia ${ }^{P}$ & & & $\mathrm{x}$ & & $\mathrm{x}$ & $x$ \\
\hline Banded Antbird Dichrozona cincta ${ }^{\mathrm{P}}$ & & & & & & $x$ \\
\hline Chestnut-tailed Antbird Myrmeciza hemimelaena ${ }^{\mathrm{P}}$ & & & & & & $x$ \\
\hline Sooty Antbird Myrmeciza fortis ${ }^{\mathrm{P}}$ & & & & & & $x$ \\
\hline White-plumed Antbird Pithys albifrons ${ }^{\mathrm{P}}$ & & & $\mathrm{x}$ & & & \\
\hline $\begin{array}{l}\text { Hairy-crested Antbird Rhegmatorhina } \\
\text { melanosticta } a^{\mathrm{P}}\end{array}$ & & & & & & $\mathrm{x}$ \\
\hline Black-faced Antthrush Formicarius analis ${ }^{P C}$ & & & & $x$ & $x$ & $x$ \\
\hline Short-tailed Antthrush Chamaeza campanisona & & & $\mathrm{x}$ & & $\mathrm{X}^{*}$ & \\
\hline Thrush-like Antpitta Myrmothera campanisona & & & $x$ & & & $x$ \\
\hline Sooty-headed Tyrannulet Phyllomyias griseiceps ${ }^{\mathrm{FC}}$ & & & & & & $x$ \\
\hline Red-billed Tyrannulet Zimmerius cinereicapillus ${ }^{\mathrm{P}}$ & & & & & & $x$ \\
\hline Golden-faced Tyrannulet Zimmerius chrysops & & & & & & $x$ \\
\hline White-lored Tyrannulet Ornithion inerme ${ }^{\mathrm{P}}$ & & & & & & $\mathrm{x}$ \\
\hline Yellow-crowned Tyrannulet Tyrannulus elatus ${ }^{\mathrm{P}}$ & & & & & & $\mathrm{x}$ \\
\hline Yellow-bellied Elaenia Elaenia flavogaster ${ }^{r}$ & & $x$ & $x$ & $x$ & & \\
\hline Scrub-flycatcher sp. Sublegatus (obscurior?) ${ }^{p}$ & & & & & & $x$ \\
\hline Torrent Tyrannulet Serpophaga cinerea & $X^{N S}$ & & $x$ & $x$ & & \\
\hline Olive-striped Flycatcher Mionectes olivaceus & & & $x$ & & & \\
\hline Ochre-bellied Flycatcher Mionectes oleagineus ${ }^{p}$ & & & & & & $x$ \\
\hline Slaty-capped Flycatcher Leptopogon superciliaris & & & & & & $\mathrm{x}$ \\
\hline Spectacled Bristle-tyrant Pogonotriccus orbitalis & & & & & & $\mathrm{x}$ \\
\hline Ringed Antpipit Corythopis torquata ${ }^{\mathrm{PC}}$ & & & $x$ & & & $\mathrm{x}$ \\
\hline $\begin{array}{l}\text { Black and White Tody-tyrant Poecilotriccus } \\
\text { capitalis }^{\mathrm{p}}\end{array}$ & & & & & & $x$ \\
\hline $\begin{array}{l}\text { Buff-throated Tody-tyrant Hemitriccus } \\
\text { rufigularis }\end{array}$ & & & & & & $\mathrm{x}$ \\
\hline Tody-tyrant sp. Hemitriccus sp. & & & $x$ & & & \\
\hline $\begin{array}{l}\text { Rusty-fronted Tody-flycatcher Todirostrum } \\
\text { latirostre }\end{array}$ & & & & & & $\mathrm{x}$ \\
\hline $\begin{array}{l}\text { Golden-winged Tody-flycatcher Todirostrum } \\
\text { calopterum }^{\mathrm{r}}\end{array}$ & & & $\mathrm{x}$ & $\mathrm{x}$ & & $\mathrm{x}$ \\
\hline Common Tody-flycatcher Todirostrum cinereum & & & & $x$ & & $x$ \\
\hline Flatbill sp. Rhynchocyclus sp. & & & & & & $x$ \\
\hline Olivaceous Flatbill Rhynchocyclus olivaceus & & & $\mathrm{x}$ & & & \\
\hline Yellow-margined Flycather Tolmomyias assimilis ${ }^{\mathrm{P}}$ & & & & & & $\mathrm{x}$ \\
\hline $\begin{array}{l}\text { Yellow-breasted Flycatcher Tolmomyias } \\
\text { flaviventris }\end{array}$ & & & & & & $x$ \\
\hline $\begin{array}{l}\text { Golden-crowned Spadebill Platyrinchus } \\
\text { coronatus }^{\mathrm{P}}\end{array}$ & & & & $x$ & & \\
\hline Ornate Flycatcher Myiotriccus ornatus & $X^{5}$ & $\mathrm{x}$ & $x$ & & $x$ & $x$ \\
\hline Ruddy-tailed Flycatcher Terenotriccus erythrurus & & & & & & $x$ \\
\hline Tawny-breasted Flycatcher Myiobius villosus & & & & & & $x$ \\
\hline Sulphur-rumped Flycatcher Myiobius barbatus & & & $\mathrm{x}$ & & & \\
\hline Black-tailed Flycatcher Myiobius atricaudus ${ }^{\mathrm{P}}$ & & & & $x$ & & \\
\hline $\begin{array}{l}\text { Olive-chested Flycatcher Myiophobus } \\
\text { cryptoxanthus }\end{array}$ & & & & & & $x$ \\
\hline Wood-Pewee sp. Contopus (sordidulus?) & & & & $x$ & & \\
\hline Euler's Flycatcher Lathrotriccus euleri ${ }^{\mathrm{P}}$ & & & & & & $x$ \\
\hline Black Phoebe Sayornis nigricans & $X^{\mathrm{NS}}$ & & $x$ & & & \\
\hline
\end{tabular}




\begin{tabular}{|c|c|c|c|c|c|c|}
\hline Species & RN & $\mathrm{s}$ & QRS & $\mathrm{MC}$ & $\mathrm{RMC}$ & M \\
\hline Cliff Flycatcher Hirundinea ferruginea & & & & & & $x$ \\
\hline Long-tailed Tyrant Colonia colonus & & $\mathrm{X}$ & & $x$ & & $\mathrm{X}$ \\
\hline Bright-rumped Attila Attila spadiceus & & & & & & $x$ \\
\hline Greyish Mourner Rhytipterna simplex ${ }^{\mathrm{P}}$ & & & & & & $x$ \\
\hline Dusky-capped Flycatcher Myiarchus tuberculifer & & & & & & $\mathrm{x}$ \\
\hline Short-crested Flycatcher Myiarchus ferox ${ }^{P}$ & & & & $x$ & & \\
\hline Boat-billed Flycatcher Megarynchus pitangua & & & & & & $\mathrm{x}$ \\
\hline Social Flycatcher Myiozetetes similis & $X^{N}$ & $\mathrm{X}$ & $X$ & $x$ & & $\mathrm{X}$ \\
\hline Grey-capped Flycatcher Myiozetetes granadensis & & & $X$ & $x$ & & $\mathrm{X}$ \\
\hline Lemon-browed Flycatcher Conopias cinchoneti & & & & & & $\mathrm{X}$ \\
\hline Tropical Kingbird Tyrannus melancholicus & $X^{\mathrm{NS}}$ & & $x$ & $x$ & & $x$ \\
\hline $\begin{array}{l}\text { Yellow-cheeked Becard Pachyramphus } \\
\text { xanthogenys }\end{array}$ & & & & & & $x$ \\
\hline $\begin{array}{l}\text { Chestnut-crowned Becard Pachyramphus } \\
\text { castaneus }^{P}\end{array}$ & & & & & & $x$ \\
\hline Black-capped Becard Pachyramphus marginatus ${ }^{\mathrm{P}}$ & & & & & $\mathrm{x}$ & $\mathrm{X}$ \\
\hline $\begin{array}{l}\text { Black-and-white Becard Pachyramphus } \\
\text { albogriseus }\end{array}$ & & & $x$ & & & \\
\hline Masked Tityra Tityra semifasciata & & $x$ & & $x$ & $x$ & \\
\hline Sharpbill Oxyruncus cristatus ${ }^{\mathrm{P}}$ & & & & & & $\mathrm{X}$ \\
\hline Fiery-throated Fruiteater Pipreola chlorolepidota ${ }^{\mathrm{P}}$ & & $\mathrm{X}$ & $\mathrm{x}$ & & & \\
\hline White-browed Purpletuft Iodopleura isabellae ${ }^{p}$ & & & & & & $\mathrm{X}$ \\
\hline Cinerous Mourner Laniocera hypopyrrha ${ }^{P}$ & & & & & & $x$ \\
\hline Elegant Mourner Laniisoma elegans & & & & & & $\mathrm{X}$ \\
\hline Grey-tailed Piha Lipaugus subalaris ${ }^{\mathrm{P}}$ & & & & & & $\mathrm{X}$ \\
\hline Amazonian Umbrellabird Cephalopterus ornatus & & & & & $\mathrm{X}$ & \\
\hline Andean Cock-of-the-rock Rupicola peruviana & & & $\mathrm{X}$ & & & $\mathrm{X}$ \\
\hline Golden-headed Manakin Pipra erythrocephala ${ }^{\mathrm{PC}}$ & & & $\mathrm{x}$ & & & $\mathrm{X}$ \\
\hline Blue-backed Manakin Chiroxiphia pareola ${ }^{\mathrm{P}}$ & & & & & & $\mathrm{X}$ \\
\hline White-bearded Manakin Manacus manacus ${ }^{\mathrm{PC}}$ & & & & $x$ & & $\mathrm{x}$ \\
\hline Striped Manakin Machaeropterus regulus ${ }^{P C}$ & & & & $\mathrm{x}$ & & \\
\hline Green Manakin Chloropipo holochlora & & & & & $\mathrm{x}$ & $\mathrm{X}$ \\
\hline Dwarf Tyrant-manakin Tyranneutes stolzmanni ${ }^{\mathrm{PC}}$ & & & $x$ & & & $\mathrm{X}$ \\
\hline Wing-barred Piprites Piprites chloris ${ }^{\mathrm{PC}}$ & & & $\mathrm{x}$ & & & $\mathrm{X}$ \\
\hline Thrush-like Mourner Schiffornis turdinus ${ }^{P C}$ & & & & & & $\mathrm{x}$ \\
\hline Violaceous Jay Cyanocorax violaceus ${ }^{\mathrm{PC}}$ & & $x$ & & & & $x$ \\
\hline $\begin{array}{l}\text { Rufous-browed Peppershrike Cyclarhis } \\
\text { gujanensis }\end{array}$ & & & & & & $\mathrm{X}$ \\
\hline Slaty-capped Shrike-vireo Vireolanius leucotis & & & $\mathrm{X}$ & & & $\mathrm{x}$ \\
\hline Red-eyed Vireo Vireo olivaceus & & & $\mathrm{x}$ & & & $\mathrm{X}$ \\
\hline Dusky-capped Greenlet Hylophilus hypoxanthus ${ }^{P}$ & & & & & & $\mathrm{X}$ \\
\hline Olivaceous Greenlet Hylophilus olivaceus & & $\mathrm{X}$ & & & & $\mathrm{X}$ \\
\hline $\begin{array}{l}\text { Tawny-crowned Greenlet Hylophilus } \\
\text { ochraceiceps }^{\mathrm{P}}\end{array}$ & & & & & & $\mathrm{X}$ \\
\hline Swainson's Thrush Catharus ustulatus & & $\mathrm{X}$ & $\mathrm{x}$ & $\mathrm{X}$ & & \\
\hline Black-billed Thrush Turdus ignobilis & $X^{N}$ & $x$ & & $x$ & & $\mathrm{X}$ \\
\hline White-necked Thrush Turdus albicolis ${ }^{\mathrm{PC}}$ & & & & & & $\mathrm{x}$ \\
\hline Blue-and-white Swallow Notiochelidon cyanoleuca & $X^{5}$ & $\mathrm{x}$ & & & & $x$ \\
\hline White-banded Swallow Atticora fasciata & $\mathrm{X}^{\mathrm{NS}}$ & $x$ & & $\mathrm{x}$ & & $\mathrm{X}$ \\
\hline White-thighed Swallow Neochelidon tibialis ${ }^{\mathrm{PC}}$ & & & & & & $\mathrm{X}$ \\
\hline $\begin{array}{l}\text { Southern Rough-winged Swallow Stelgidopteryx } \\
\text { ruficollis }\end{array}$ & $x^{s}$ & & & $\mathrm{X}$ & & $\mathrm{x}$ \\
\hline Barn Swallow Hirundo rustica & $X^{\mathrm{N}}$ & & $X$ & & & \\
\hline Thrush-like Wren Campylorhynchus turdinus & & & & $\mathrm{x}$ & & $\mathrm{x}$ \\
\hline
\end{tabular}




\begin{tabular}{|c|c|c|c|c|c|c|}
\hline Species & $\mathrm{RN}$ & $S$ & QRS & $\mathrm{MC}$ & $\mathrm{RMC}$ & M \\
\hline Coraya Wren Thryothorus coraya ${ }^{\mathrm{P}}$ & & $x$ & & & & $\mathrm{x}$ \\
\hline House Wren Troglodytes aedon & $\mathrm{X}^{\mathrm{N}}$ & & & $\mathrm{x}$ & & $\mathrm{x}$ \\
\hline $\begin{array}{l}\text { White-breasted Wood-wren Henicorhina } \\
\text { leucosticta }\end{array}$ & & $\mathrm{x}$ & & $\mathrm{X}$ & $\mathrm{X}$ & \\
\hline Musician Wren Cyphorhinus arada & & & & & & $x$ \\
\hline $\begin{array}{l}\text { Southern Nightingale-wren Microcerculus } \\
\text { marginatus }^{\mathrm{P}}\end{array}$ & & & $x$ & $\mathrm{x}$ & & $x$ \\
\hline Tawny-faced Gnatwren Microbates cinereiventris ${ }^{\mathrm{P}}$ & & & & & & $x$ \\
\hline Tropical Parula Parula pitiayumi & & & & & $x$ & $x$ \\
\hline Blackburnian Warbler Dendroica fusca & & $x$ & $x$ & & & \\
\hline Canada Warbler Wilsonia canadensis & & $x$ & $x$ & $x$ & $x$ & \\
\hline Slate-throated Whitestart Myioborus miniatus & & & $x$ & & & $\mathrm{x}$ \\
\hline Three-striped Warbler Basileuterus tristriatus & & & & & & $x$ \\
\hline Buff-rumped Warbler Basileuterus fulvicauda & $X^{\text {NS }}$ & & & $x$ & & $x$ \\
\hline Banaquit Coereba flaveola & $X^{\mathrm{N}}$ & $\mathrm{x}$ & $x$ & $\mathrm{x}$ & & $\mathrm{x}$ \\
\hline Purple Honeycreeper Cyanerpes caeruleus & & & $x$ & & & \\
\hline Green Honeycreeper Chlorophanes spiza & & & & & & $x$ \\
\hline Blue Dacnis Dacnis cayana & & & & & & $x$ \\
\hline Black-faced Dacnis Dacnis lineata & $X^{5}$ & & $\mathrm{x}$ & & $x$ & $\mathrm{X}$ \\
\hline Yellow-bellied Dacnis Dacnis flaviventer ${ }^{\mathrm{PC}}$ & $x^{\mathrm{s}}$ & & $\mathrm{x}$ & & & $\mathrm{X}$ \\
\hline Deep-blue Flower-piercer Diglossa glauca & & & & $\mathrm{x}$ & & \\
\hline Yellow-backed Tanager Hemithraupis flavicollis ${ }^{\mathrm{P}}$ & & & $x$ & & & $\mathrm{X}$ \\
\hline Golden-rumped Euphonia Euphonia cyanocephala & & & & & $\mathrm{X}^{*}$ & $\mathrm{X}$ \\
\hline Orange-bellied Euphonia Euphonia xanthogaster & & & $\mathrm{x}$ & $x$ & $\mathrm{x}$ & $x$ \\
\hline Rufous-bellied Euphonia Euphonia rufiventris ${ }^{P}$ & & & & & & $\mathrm{X}$ \\
\hline Bronze-green Euphonia Euphonia mesachrysa & & & & & & $\mathrm{X}$ \\
\hline White-lored Euphonia Euphonia chysopasta & & & & & & $\mathrm{x}$ \\
\hline Orange-eared Tanager Chlorochrysa calliparaea & & & $\mathrm{x}$ & & $x$ & \\
\hline Golden Tanager Tangara arthus & & & $x$ & & $x$ & \\
\hline Golden-eared Tanager Tangara chrysotis & & & & & $x$ & \\
\hline Blue-browed Tanager Tangara cyanotis & & & & & $\mathrm{x}$ & \\
\hline Blue-necked Tanager Tangara cyanicollis & & $x$ & $x$ & $x$ & $x$ & $x$ \\
\hline Masked Tanager Tangara nigrocincta & & & & & & $x$ \\
\hline Turquoise Tanager Tangara mexicana & & $x$ & & & & \\
\hline Paradise Tanager Tangara chilensis & & $x$ & $\mathrm{x}$ & & $x$ & $\mathrm{X}$ \\
\hline Green-and-gold Tanager Tangara schrankii & & $x$ & $\mathrm{X}$ & & $X$ & $\mathrm{X}$ \\
\hline Spotted Tanager Tangara puncata & & & $x$ & & $\mathrm{X}$ & \\
\hline Yellow-bellied Tanager Tangara xanthogastra & & & & & & $\mathrm{X}$ \\
\hline Bay-headed Tanager Tangara gyrola & & $\mathrm{x}$ & $x$ & & $X$ & $X$ \\
\hline $\begin{array}{l}\text { Blue-winged Mountain-tanager Anisognathus } \\
\text { flavinucha }\end{array}$ & & & & & $\mathrm{X}$ & \\
\hline $\begin{array}{l}\text { Orange-throated tanager Wetmorethraupis } \\
\text { sterrhopteron }^{\mathrm{P}}\end{array}$ & & & & & & $\mathrm{x}$ \\
\hline Swallow Tanager Tersina viridis ${ }^{\mathrm{PC}}$ & & & & $\mathrm{x}$ & $x$ & \\
\hline Blue-grey Tanager Thraupis episcopus & & $x$ & $x$ & $x$ & & $x$ \\
\hline Palm Tanager Thraupis palmarum & & $x$ & $x$ & $\mathrm{x}$ & & \\
\hline Silver-beaked Tanager Ramphocelus carbo & $X^{N}$ & $x$ & $x$ & $x$ & & $x$ \\
\hline Vermilion Tanager Calochaetes coccineus & & & & & $x$ & \\
\hline Summer Tanager Piranga rubra & & & & $x$ & & \\
\hline White-winged Tanager Piranga leucoptera & & & & & $\mathrm{X}^{*}$ & \\
\hline Fulvous Shrike-tanager Lanio fulvus & & & $x$ & & $\mathrm{x}$ & $x$ \\
\hline $\begin{array}{l}\text { Flame-creasted Tanager Tachyphonus } \\
\text { cristatus }^{P}\end{array}$ & & & & & & $x$ \\
\hline $\begin{array}{l}\text { Ashy-throated Bush-tanager Chlorospingus } \\
\text { canigularis }\end{array}$ & & & & & $\mathrm{X}$ & \\
\hline
\end{tabular}




\begin{tabular}{|c|c|c|c|c|c|c|}
\hline Species & RN & $s$ & QRS & $\mathrm{MC}$ & RMC & M \\
\hline \multicolumn{7}{|l|}{$\begin{array}{l}\text { Yellow-throated Bush-tanager Chlorospingus } \\
\text { flavigularis }\end{array}$} \\
\hline Magpie Tanager Cissopis leveriana & & $\mathrm{x}$ & $\mathrm{x}$ & $x$ & & $\mathrm{x}$ \\
\hline Greyish Saltator Saltator coerulescens & & $x$ & & $x$ & $x$ & $x$ \\
\hline Buff-throated Saltator Saltator maximus & & & $\mathrm{x}$ & & & $x$ \\
\hline Slate-coloured Grosbeak Saltator grossus & & & & $\mathrm{x}$ & & $x$ \\
\hline Blue-black Grosbeak Cyanocompsa cyanoides ${ }^{\mathrm{P}}$ & & & & & & $x$ \\
\hline \multicolumn{7}{|l|}{$\begin{array}{l}\text { Yellow-shouldered Grosbeak Caryothraustes } \\
\text { humeralis }^{P}\end{array}$} \\
\hline Black-and-white Seedeater Sporophila luctuosa & & & & $\mathrm{x}$ & & \\
\hline \multicolumn{7}{|l|}{ Chestnut-bellied Seedeater Sporophila } \\
\hline Lesser Seed-Finch Oryzoborus angolensis & & & & $x$ & & $\mathrm{x}$ \\
\hline Yellow-browed Sparrow Ammodramus aurifrons & $X^{N}$ & $x$ & & $x$ & & $x$ \\
\hline Giant Cowbird Scaphidura oryzivora ${ }^{\mathrm{PC}}$ & & & & $\mathrm{X}$ & & \\
\hline $\begin{array}{l}\text { Russet-backed Oropendola } P_{\text {sarocolius }} \\
\text { angustifrons }\end{array}$ & $X^{N}$ & & $\mathrm{x}$ & $x$ & $\mathrm{X}$ & $\mathrm{x}$ \\
\hline Yellow-rumped Cacique Cacicus cela ${ }^{\mathrm{p}}$ & & $x$ & $x$ & $x$ & & \\
\hline Ecuadorian Cacique Cacicus sclateri ${ }^{\mathrm{P}}$ & & & & & & $x$ \\
\hline \multirow[t]{2}{*}{ Orange-billed Sparrow Arremon aurantiirostris } & & $\mathrm{x}$ & & & $\mathrm{x}$ & $\mathrm{x}$ \\
\hline & 39 & 48 & 90 & 71 & 63 & 208 \\
\hline
\end{tabular}

\section{References}

Anon. (1978) Characteristicas socio-economicas del grupo Shuar: Valles de NangaritzaZamora-Yacuambi, Provincia de Zamora-Chinchipe. Quito, Ecuador: Subcomision Ecuatoriana Predesur.

Chapman, F. M. (1926). The distribution of bird-life in Ecuador: a contribution to the study of the origins of Andean bird-life. Bull. Amer. Mus. Nat. Hist. 55: 1-784.

Collar, N. J., Gonzaga, L. P., Krabbe, N., Madroño Nieto, A., Naranjo, L. G., Parker, T. A. and Wege, D. (1992) Threatened birds of the Americas: the ICBP/IUCN Red Data Book. Third edition (Part 2). Cambridge, U.K.: International Council for Bird Preservation.

Collar, N. J., Crosby, M. J. and Stattersfield, A. J. (1994) Birds to watch 2: the world list of threatened birds. Cambridge, U.K.: BirdLife International.

Doltz, J. G. (1989) Gold mining in Zamora Province. Small Mining Inst. Bull. 7 .

Hilty, S. L. and Brown, W. L. (1986) Birds of Colombia. Princeton: Princeton University Press.

Krabbe, N. and Sornoza, M. F. (1994) Avifaunistic results of a subtropical camp in the Cordillera del Condor, southeastern Ecuador. Bull. Brit. Orn. Club 114: 55-61.

Marín A., M., Carrión, J. M. and Sibley, F. C. (1992) New distributional records for Ecuadorian birds. Om. Neotropical 3: 27-34.

Palacios, W. A. (1997) Botany and landscape of the Rio Nangaritza basin. Pp. 37-44 in T. S. Schulenberg and K. Awbrey, eds. The Cordillera del Condor of Ecuador and Peru: $a$ biological assessment. RAP Working Papers 7. Washington, D.C.: Conservation International.

Poulsen, M. K. and Wege, D. C. (1994) Coppery-chested Jacamar Galbula pastazae. Cotinga 2: $60-62$.

Rahbek, C. and Toyne, E. P. (1996a) Río Bombuscara. Pp. 322-324 in R. S. R. Williams, B. J. Best and T. Heijen, eds. A guide to birdwatching in Ecuador and the Galápagos Islands. Leeds, U.K.: Biosphere Publications.

Rahbek, C. and Toyne, E. P. (1996b) Romerillos. Pp. 325-326 in R. S. R. Williams, B. J. Best 
and T. Heijen, eds. A guide to birdwatching in Ecuador and the Galápagos Islands. Leeds, U.K.: Biosphere Publications.

Rahbek, C., Bloch, B., Poulsen, M. K. and Rasmussen, J. F. (1995) The avifauna of Podocarpus National Park - the "Andean jewel in the crown" of Ecuador's protected areas. Orn. Neotropical 6: 113-120.

Rasmussen, J. F., Rahbek, C., Horstman, E., Poulsen, M. K. and Bloch, H. (1994) Birds of Podocarpus National Park an annotated checklist. Quito, Ecuador: CECIA.

Rasmussen, J. F., Rahbek, C., Poulsen, B. O., Poulsen, M. K. and Bloch, H. (1996) Distributional records and natural history notes on threatened and little known birds of southern Ecuador. Bull. Brit. Orn. Club. 116: 26-46.

Ridgely, R. S. (1980) Notes on some rare or previously unrecorded birds in Ecuador. Am. Birds 34: 242-248.

Ridgely, R. S. and Tudor, G. (1989) Birds of South America, 1. The Oscine Passerines. Oxford: Oxford University Press.

Ridgely, R. S. and Tudor, G. (1994) Birds of South America, 2. The Suboscine Passerines. Oxford: Oxford University Press.

Robbins, M. B., Ridgely, R. S., Schulenburg, T. S. and Gill, F. B. (1987) The avifauna of the Cordillera de Cutucú, Ecuador, with comparisons to other Andean localities. Proc. Acad. Nat. Sci. Philadelphia 139: 243-259.

Schulenberg, T. S. and Awbrey, K. (1997) The Cordillera del Condor of Ecuador and Peru: A biological assessment. RAP Working Papers 7. Washington, D.C.: Conservation International.

Toyne, E. P. and Balchin, C. S. (1996) Río Nangaritza. Pp. 327-328 in R. S. R. Williams, B. J. Best, and T. Heijen, eds. A guide to birdwatching in Ecuador and the Galápagos Islands. Leeds, U.K.: Biosphere Publications.

Toyne, E. P., Jeffcote, M. T., and Flanagan, J. N. M. (1992) Status, distribution and ecology of the White-breasted Parakeet Pyrrhura albipectus in Podocarpus National Park, southern Ecuador. Bird Conserv. Int. 2: 327-339.

Vallée, D. (1992) Environmental impacts of gold mining in Podocarpus National Park in southern Ecuador. Unpublished MSc thesis. Imperial College of Science, Technology and Medicine, London.

Wege, D. C. and Long, A. J. (1995) Key areas for threatened birds in the Neotropics. Cambridge, U.K.: BirdLife International (BirdLife Conservation Series 5).

C. S. BALCHIN

24 Juniper Close, Towcester, Northamptonshire NN12 6XP, U.K.

E. P. TOYNE

Department of Biology, Imperial College, London $S_{7} 2 B B$.

Present address: WWF-UK, Panda House, Weyside Park, Catteshall Lane, Godalming, Surrey GUT IXR, U.K. 